INTERNATIONAL JOURNAL OF PLANT PROTECTION VOLUME 9 | ISSUE 2 | OCTOBER, 2016 | 532-535
- e ISSN-0976-6855 | Visit us : www.researchjournal.co.in

\title{
Influence of various botanicals as soil amendment in the management of Fusarium oxysporum f. spp. vigni causing wilt in mungbean [Vigna radiata (L.) Wilczek]
}

\section{BHUPENDRA THAKRE* AND JYANT BHAT}

Zonal Agriculture Research Station (J.N.K.V.V.), CHHINDWARA (M.P.) INDIA

Department of Plant Pathology, College of Agriculture, Jawaharlal Nehrau Krishi Vishwa Vidyalaya, JABALPUR (M.P.) INDIA

\section{ARITCLE INFO}

Received : 08.08 .2016

Revised : 01.09 .2016

Accepted : 15.09 .2016

\section{KEY WORDS :}

Mung bean, Wilt, Botanicals, Leaf powder, Soil amendment, Plant mortality

*Corresponding author:

\section{ABSTRACT}

The experiment was conducted in pots under glass house condition where leaf powder of nine plants extracts i.e. Neem (Azadirachta indica), Karanj (Pongamia pinnata), Babul (Acacia nilotica), Nilgiri (Eucalyptus tereticornis), Jatropha curcas (Jatropha) Ashok (Polyalthia longifolia), Tulsi (Ocimum sanctum), Bougainvillea (Bougainvillea sp.) and Mehndi (Lawsonia alba) were mixed with soil @ $40 \mathrm{~g} / \mathrm{kg}$ soil. Showed antifungal properties of leaves were tested as soil amendment against Fusarium oxysporum f. spp. vigni the plant grown on Neem amended soil minimum plant mortality recorded

How to view point the article : Thakre, Bhupendra and Bhat, Jyant (2016). Influence of various botanicals as soil amendment in the management of Fusarium oxysporum f. spp. vigni causing wilt in Mung bean [Vigna radiata (L.) Wilczek]. Internat. J. Plant Protec., 9(2) : $532-$ 535, DOI : 10.15740/HAS/IJPP/9.2/532-535. 